\title{
Defined Substance Administration Dose Period Code
}

National Cancer Institute

\section{Source}

National Cancer Institute. Defined Substance Administration Dose Period Code. NCI

Thesaurus. Code C93798.

A coded value specifying the period during which the periodDoseT otal is administered. 